\title{
Long-term rice-based cropping system effects on near-surface soil compaction
}

\author{
Jill M. Motschenbacher, Kristofor R. Brye*, Merle M. Anders
}

Department of Crop, Soil, and Environmental Sciences, University of Arkansas, Fayetteville, USA;

*Corresponding Author: kbrye@uark.edu

Received 7 February 2011; revised 3 March 2011; accepted 30 March 2011.

\begin{abstract}
Irrigated rice (Oryza sativa L.) production is associated with frequent cycling between anaerobic and aerobic conditions, which can lead to a greater rate of soil organic matter (SOM) decomposition, thus potentially increasing soil bulk density (BD) over time. A study was conducted in the Mississippi River Delta region of eastern Arkansas, USA to evaluate the long-term effects of rice-based crop rotations, tillage [conventional tillage (CT) and no-tillage (NT)], soil fertility regime (optimal and sub-optimal), and soil depth (0-10 and 10-20 cm) after 10 years of consistent management on near-surface soil compaction, as measured by BD. Soil BD was greater under NT than CT in the top $10 \mathrm{~cm}$, but was similar between NT and CT in the 10- to $20-\mathrm{cm}$ depth interval. Soil BD differed among common ricebased cropping systems with corn, soybean, and winter wheat, but few consistent trends were evident. It appears that, even after 10 years of continuous CT or NT rice production on a siltloam soil, substantially increased near-surface soil BD has not occurred to the point where soil compaction would be a likely culprit responsible for a reduced early season stand establishment or crop yield differences among ricebased copping systems.
\end{abstract}

Keywords: Bulk Density; Crop Rotation; Soil Organic Matter; Tillage

\section{INTRODUCTION}

The enhancement of soil quality is vital to sustaining and improving long-term agricultural productivity, namely crop yields $[1,2]$. Soil bulk density (BD), the ratio of the dry soil mass to the volume it occupies, is often one of a suite of measured soil properties that is an indicator of soil quality $[1,3,4]$. Soil BD is related to soil compaction in that $\mathrm{BD}$ is relatively greater in compacted than in non-compacted soil. Compacted soil with a relatively large BD can negatively affect numerous soil and plant properties and processes. Soil BD has been shown to be directly related to soil strength [5-9] and soil penetration resistance [10-14], which is another soil property that is often used to quantify soil compaction. In contrast, soil $\mathrm{BD}$ has been shown to be inversely related to soil organic matter (SOM) [6,15], water-holding capacity [6,14, 16], soil particle size [17], total porosity [18-20], infiltration capacity $[6,21,22]$, hydraulic conductivity $[14,18$, 20], gas exchange [23], nutrient mobility [6,24], and invertebrate movement $[12,25]$. Similarly, soil BD has been shown to be inversely related to seedling emergence $[19,26]$ and root penetration $[6,12,14,16]$, both of which can negatively affect yield if soil compaction is severe.

Soil BD has also been shown to be affected by several crop management practices, particularly tillage and crop rotation [14,27-30]. Soil BD is generally greater under reduced tillage, specifically no-tillage (NT), due to machinery traffic and the lack of surface soil disruption and mixing accomplished by annual plowing $[16,18,20,29$, 31,32]. Since soil BD has been shown to be inversely related to SOM [6,15], where increasing SOM generally decreases soil BD by adding additional pore space without adding much additional mass, crop rotations with a large frequency of high-residue-producing crops that are managed using cultural practices that return crop residues to the soil could consequently at least maintain a near-surface soil BD that is favorable for gas exchange, water infiltration, and plant growth.

Rice (Oryza sativa L.) is one of several high-residueproducing crops, along with corn (Zea mays L.) and winter wheat (Triticum aestivum L.), that is capable of producing $8.1 \mathrm{Mg} \cdot \mathrm{ha}^{-1}$ of above-ground biomass under optimal nitrogen fertilization [33,34]. Of the roughly 1.2 million ha of rice planted and 9.3 million $\mathrm{Mg}$ of rice grain produced in the United States annually, over $46 \%$ of the total rice area $(566,800 \mathrm{ha})$ and over $45 \%$ of the 
total grain production (4.2 million Mg) occur in the Mississippi River Delta region of eastern Arkansas [35]. However, rice is unlike all other row crops in that rice is most frequently grown under flood-irrigated conditions after about one month post-emergence, where the uppermost part of the soil profile is nearly to completely saturated [36]. To harvest rice, the flood must be released several weeks prior to the targeted harvest window in order to allow the soil to drain and dry out to achieve enough structural stability to support heavy harvesting machinery. If the soil is too wet and not sufficiently dry to provide structural support for a large harvest combine, rice fields are often severely rutted, which can result in elevated soil BD and compaction in many areas of a field [37].

Furthermore, the decomposition of SOM is generally slower in waterlogged soil than in well-aerated soil [2, 36]. However, flood-irrigated rice fields are unique from other wetland soils in that they are often relatively dry between successive rice crops in the rotation. Aerobic soil conditions also exist during the dry periods between flooding and heavy precipitation, which stimulates the rapid breakdown of accumulated SOM. This decline in SOM can, in turn, adversely affect soil productivity, soil quality, and the overall sustainability of rice production [38]. The frequent cycling between anaerobic and aerobic conditions can potentially lead to a greater rate of SOM decomposition [39], which could essentially increase the BD of the soil. Increasing soil BD over time is a reasonable concern because compacted soil may hinder short-term plant growth and long-term crop yield.

Since the nature of soil physical properties are generally of little concern during a rice crop-growing season due to the flooded-soil conditions, relatively few studies have examined the potential effects of rice rotations on soil physical properties, particularly soil BD. Therefore, the objective of this study was to evaluate the long-term effects of rice-based crop rotations, tillage [conventional tillage (CT) and no-tillage (NT)], soil fertility regime (optimal and sub-optimal), and soil depth (0-10 and 10$20 \mathrm{~cm}$ ) after 10 years of consistent management on nearsurface soil compaction, as measured by soil BD, in the Mississippi River Delta region of eastern Arkansas. It was hypothesized that soil BD would be i) similar among soil depths under CT due to the mixing action of mechanical cultivation, but greater in the 10-20 than in the $0-10 \mathrm{~cm}$ depth interval under NT, ii) different among rice-based cropping systems and that the difference would be related to the frequency of rice and other high-residue-producing crops in the rotation, and iii) generally lower under optimal than sub-optimal fertilization due to greater SOM.

\section{SITE DESCRIPTION}

This study was conducted at the University of Arkansas Rice Research and Extension Center (RREC) near Stuttgart, AR $\left(34^{\circ} 27^{\prime} \mathrm{N}, 91^{\circ} 24^{\prime} \mathrm{W}\right)$, which is located in the Mississippi River Delta region of eastern Arkansas in an area known as the Grand Prairie. This study was initiated in 1999 on a Dewitt silt loam (fine, smectitic, thermic, Typic Albaqualf) [40], which is characteristic of Grand Prairie soils used for rice production.

Prior to 1999, the study area had been fallow for several years due to a lack of irrigation capability. Vegetation present consisted of a mixture of grasses and weeds that were managed by periodic mowing during the summer. In preparation for this study, the site was land-leveled to a $0.15 \%$ grade in fall 1998 . Land-leveling consisted of removing and piling the top $10 \mathrm{~cm}$ of soil off to the side of the area to be leveled, cutting the field to grade, and redistributing the topsoil uniformly over the field. Land-leveling is a common practice in the Mississippi River Delta region, especially in areas where rice production dominates, to facilitate uniform distribution of flood-irrigation water [41].

The climate of the region is warm and wet with a $30-y r$ mean annual temperature minimum of $0.22^{\circ} \mathrm{C}$ in January and maximum of $33.1^{\circ} \mathrm{C}$ in July. The $30-y r$ mean annual precipitation is $131.6 \mathrm{~cm}$ [42].

\section{FIELD TREATMENTS AND EXPERI- MENTAL DESIGN}

This field study consisted of two tillage treatments [conventional tillage (CT) and no-tillage (NT)], two soil fertility treatments (optimal and sub-optimal), and 10 rice-cropping systems arranged in a randomized complete block with four replications (i.e., blocks) of treatment combinations. Each block occupied an area of 120 $\mathrm{m}$ long by $76-\mathrm{m}$ wide $\left(9120 \mathrm{~m}^{2}\right)$. Soil fertility treatments were imposed as a split of each tillage treatment, while the rice rotations were horizontally stripped across the tillage-fertility combinations. Each tillage-fertility-rotation combination represented the experimental unit and had dimensions of 19- by 6-m.

The optimal soil fertility treatment followed a standard fertility recommendation based on the analysis of soil samples that were collected in spring 1999 (Table 1). The annual soil fertility treatment consisted of $\mathrm{P}_{2} \mathrm{O}_{5}$ applied as triple super phosphate and $\mathrm{K}_{2} \mathrm{O}$ applied as muriate of potash, with both fertilizers broadcast pre-plant and pre-tillage with a spreader. Nitrogen as urea was applied with a hand-spreader pre-flood at the 5-leaf stage of rice growth approximately one month after planting. Phosphorous and potassium were incorporated into the soil under CT and were left at the surface under NT. 
Table 1. Summary of the $\mathrm{N}, \mathrm{P}_{2} \mathrm{O}_{5}$, and $\mathrm{K}_{2} \mathrm{O}$ added to corn, soybean, rice, and wheat to comprise the sub-optimal and optimal soil fertility treatments in a long-term rotation study at the RREC near Stuttgart, AR on a silt-loam soil.

\begin{tabular}{|c|c|c|c|}
\hline \multirow{2}{*}{ Crop } & \multirow{2}{*}{ Nutrient } & \multicolumn{2}{|c|}{ Soil Fertility $\left(\mathrm{kg} \cdot \mathrm{ha}^{-1}\right)$} \\
\hline & & Sub-Optimal & Optimal \\
\hline \multirow{3}{*}{ Corn } & $\mathrm{N}$ & 224 & 337 \\
\hline & $\mathrm{P}_{2} \mathrm{O}_{5}$ & 67 & 90 \\
\hline & $\mathrm{K}_{2} \mathrm{O}$ & 112 & 168 \\
\hline \multirow{3}{*}{ Soybean } & $\mathrm{N}$ & 0 & 0 \\
\hline & $\mathrm{P}_{2} \mathrm{O}_{5}$ & 45 & 67 \\
\hline & $\mathrm{K}_{2} \mathrm{O}$ & 67 & 135 \\
\hline \multirow{3}{*}{ Rice } & $\mathrm{N}$ & 112 & 168 \\
\hline & $\mathrm{P}_{2} \mathrm{O}_{5}$ & 45 & 67 \\
\hline & $\mathrm{K}_{2} \mathrm{O}$ & 67 & 101 \\
\hline \multirow{3}{*}{ Wheat } & $\mathrm{N}$ & 112 & 168 \\
\hline & $\mathrm{P}_{2} \mathrm{O}_{5}$ & 34 & 67 \\
\hline & $\mathrm{K}_{2} \mathrm{O}$ & 34 & 67 \\
\hline
\end{tabular}

Following nitrogen fertilization, a 5- to 10 -cm deep permanent flood was established, which was maintained annually on all of the rice plots until the rice reached physiological maturity. All other summer crops present in a given year were furrow-irrigated on an as-needed basis approximately 3 to 4 times annually, which was effectively based on the amount of rainfall received and the growth of the crop. Winter wheat was rain fed only without irrigation.

Crop varieties included in the rotation treatment of this study consisted of the major agronomic crops grown in Arkansas. Crop rotations included: continuous rice (R), rice-soybean (RS), soybean-rice (SR), rice-corn (RC), corn-rice (CR), rice (winter wheat) $[\mathrm{R}(\mathrm{W})]$, rice (winter wheat)-soybean (winter wheat) $[\mathrm{R}(\mathrm{W}) \mathrm{S}(\mathrm{W})]$, soybean (winter wheat)-rice (winter wheat) $[S(W) R(W)]$, ricesoybean-corn (RSC), and rice-corn-soybean (RCS). 'Wells' was the rice cultivar grown based on its local popularity among rice producers. Rice, soybean, and wheat were sown into $19-\mathrm{cm}$ rows in tillage treatments using an Almaco NT drill (Almaco, Nevada, IA). The rice was drill-seeded at a rate of $100 \mathrm{~kg}$ seed $\mathrm{ha}^{-1}$, soybean at a rate of $56 \mathrm{~kg}$ seed $\mathrm{ha}^{-1}$, and wheat at a rate of $67 \mathrm{~kg}$ seed ha ${ }^{-1}$. Corn was planted in $76-\mathrm{cm}$ rows at a plant population of 79,040 seeds $\mathrm{ha}^{-1}$ [43].

Rice management practices closely followed the University of Arkansas Cooperative Extension Service recommendations for stand establishment, irrigation management, and pest management [44]. In CT plots, crop residues were burned and incorporated into the soil generally one to two months following harvest by disking twice. Prior to planting in the spring, plots were tilled by disking once, followed by multiple passes of a light field cultivator (i.e., Triple-K) to achieve the desired seedbed for rice planting. In NT plots, crop residues were left on the surface after harvest and were not manipulated by any means prior to planting in the spring.
Weed management for rice [44], soybean [45], corn [46], and wheat [47] followed recommendations made by the Arkansas Cooperative Service. Weed management for rice consisted of a pre-emergence application of 0.34 $\mathrm{kg} \cdot \mathrm{ha}^{-1}$ of clomazone [2-[(2-chlorobenzyl)methyl]-4, 4dimethyl-3-isoxaolidinone] and a post-emergent application of halosulfuron [3-chloro-5-[[[[(4,6-dimethoxy-2pyrimidinyl)amino]carbonyl]amino]sulfonyl]-1-methyl1H-pyrazole-4-carcoxylic acid] at $0.06 \mathrm{~kg} \cdot \mathrm{ha}^{-1}$ for both tillage treatments. Soybean and corn were treated of 0.06 $\mathrm{kg} \cdot \mathrm{ha}^{-1}$ of glyphosate [N-(phosphonomethyl)glycine] in the spring and applications of paraquat [1,1'-dimethyl-4, 4'-bipyridinium ion] and flumioxazin [2-[7-fluro-hydro-3 -oxo-4-(2-propynyl)-2H-1,4-benzoxazin-6-yl]-4,5,6,7-tetrahydro-1H-isoindole-1,3(2H)-dione] in the fall following harvest and winter-wheat planting. Corn also received a treatment of $2.3 \mathrm{~L} \cdot \mathrm{ha}^{-1}$ of glufosinate-ammonium [2amino-4-(hydroxymethylphosphinyl)butanoic acid monoammonium salt] and $0.07 \mathrm{~L}^{-h^{-1}}$ of halosulfuron [3chloro-5-[[[[(4,6-dimethoxy-2-pyrimidinyl)amino]carbonyl]amino]sulfonyl]-1-methyl-1H-pyrazole-4-carcoxylicacid]. Wheat was treated with $0.35 \mathrm{~L} \cdot \mathrm{ha}^{-1}$ of mesosulfuron-methyl [methyl 2-[[[[(4,6-dimethoxy-2-pyrimidinyl) amino]car-bonyl]amino]sulfonyl]-4-[[(methylsulfonyl)amino]methyl] benzoate].

\section{SOIL SAMPLING}

At the time of soil sampling, the $\mathrm{R}$ and $\mathrm{R}(\mathrm{W})$ rotations had produced a total of 10 rice crops, the RS, SR, RC, $\mathrm{CR}, \mathrm{R}(\mathrm{W}) \mathrm{S}(\mathrm{W})$, and $\mathrm{S}(\mathrm{W}) \mathrm{R}(\mathrm{W})$ rotations had produced five rice crops with five crops in the respective rotation with corn or soybean, and the RSC and RCS rotations had produced four rice crops with three crops in the respective rotations with corn and soybean (Table 2). Furthermore, the plots that were rotated with winter wheat produced a total of 10 wheat crops. The CT treatment was imposed on all plots five months (late-October 2008) prior to soil BD sampling. Soil BD samples were collected in mid-March 2009 from the 0- to 10- and 10- to 20 -cm depth intervals using a $4.7-\mathrm{cm}$ diameter, stainless steel core chamber that was beveled to the outside to minimize compaction upon sampling. One BD sample was collected from each depth (0- to $10-\mathrm{cm}$ and $10-$ to $20-\mathrm{cm}$ ) per plot at a random location between previously planted rows, for a total of 320 samples. Soil samples were oven-dried at $70^{\circ} \mathrm{C}$ for 3 days and weighed to determine soil BD by dividing the oven-dry soil mass by the sample volume. After weighing, samples were ground to pass a 2-mm mesh screen to determine SOM concentration by weight-loss-on-ignition at $360^{\circ} \mathrm{C}$ for 2 hours.

Though soil BD was not measured at the onset of the study in spring 1999, land-leveling activities uniformly affected the entire study area and 10 years of consistent 
Table 2. Summary of the crop rotations and the number of rice crops and the respective rotations grown during the 10-yr study period at the RREC near Stuttgart, AR on a silt-loam soil. Crops in parentheses were grown during the winter.

\begin{tabular}{lcccc}
\hline \multirow{2}{*}{ Rotation } & \multicolumn{4}{c}{ Number of Crops } \\
\cline { 2 - 5 } & Rice & Corn & Soybean & Wheat \\
\hline Continuous Rice & 10 & - & - & - \\
Rice-Soybean & 5 & - & 5 & - \\
Soybean-Rice & 5 & - & 5 & - \\
Rice-Corn & 5 & 5 & - & - \\
Corn-Rice & 5 & 5 & - & - \\
Rice-(Wheat) & 10 & - & - & 10 \\
Rice-(Wheat)-Soybean-(Wheat) & 5 & - & 5 & 10 \\
Soybean-(Wheat)-Rice-(Wheat) & 5 & - & 5 & 10 \\
Rice-Soybean-Corn & 4 & 3 & 3 & - \\
Rice-Corn-Soybean & 4 & 3 & 3 & - \\
\hline
\end{tabular}

management has elapsed. Therefore, it was reasonably assumed that any observed differences in soil BD among treatment combinations from the 2009 sampling represented actual treatment effects rather than residual effects from inherent differences among plots from the beginning of the study.

\section{DATA ANALYSES}

The effects of tillage, fertility, crop rotation, soil depth, replication and their interactions on soil BD and SOM were evaluated by analysis of variance (ANOVA) using the Mixed Model procedure in SAS (version 9.2, SAS Institute, Inc., Cary, NC). When appropriate, means were separated using Fisher's protected least significant difference (LSD) at the 0.05 level. In addition, linear correlation analyses were conducted to identify the relationship between soil BD and SOM for each soil depth interval separate and combined within rotation treatments (version 13.31, Minitab, Inc., State College, PA).

\section{RESULTS AND DISCUSSION}

After 10 years of consistent rotation and fertility management and nine years of CT or NT, soil BD was affected by all treatments evaluated in this study. Statistical analyses showed that soil BD differed among tillage-soil depth treatment combinations ( $\mathrm{P}=0.021$; Table 3) and rotation-tillage-fertility treatment combinations ( $\mathrm{P}$ $=0.002$; Table 3 ). There were no statistically significant block effects caused by treatment replications, so all interactions observed were exclusively a result of the imposed treatments.

In the 0 - to 10 -cm depth interval, soil BD was $2.38 \%$ greater $(\mathrm{P}=0.021)$ under NT $\left(1.29 \mathrm{~g} / \mathrm{cm}^{3}\right)$ than CT $(1.26$ $\mathrm{g} / \mathrm{cm}^{3}$; Figure 1). Since SOM concentration did not differ between tillage treatments (Table 3 ), the greater BD near the soil surface under NT can be explained by the
Table 3. Analysis of variance summary of the effects of tillage, soil fertility, crop rotation, and soil depth on soil bulk density (BD) and soil organic matter content (SOM) during the 10-year rotation study at the RREC near Stuttgart, AR on a silt-loam soil.

\begin{tabular}{|c|c|c|}
\hline Treatment Effect $^{\mathrm{z}}$ & $\mathrm{BD}$ & SOM \\
\hline & \multicolumn{2}{|c|}{$\longrightarrow P=$} \\
\hline Tillage & 0.229 & 0.110 \\
\hline Fertility & 0.452 & 0.029 \\
\hline Tillage *Fertility & 0.797 & 0.702 \\
\hline Rotation & $<0.001$ & 0.333 \\
\hline Rotation *Tillage & 0.020 & 0.613 \\
\hline Rotation *Fertility & 0.995 & 0.792 \\
\hline Rotation *Tillage *Fertility & 0.002 & 0.296 \\
\hline Depth & 0.001 & $<0.001$ \\
\hline Depth *Tillage & 0.021 & 0.081 \\
\hline Depth *Fertility & 0.598 & 0.268 \\
\hline Depth *Rotation & 0.160 & 0.050 \\
\hline Depth *Tillage *Fertility & 0.767 & 0.530 \\
\hline Depth *Tillage *Rotation & 0.301 & 0.215 \\
\hline Depth *Fertility *Rotation & 0.969 & 0.078 \\
\hline Depth *Tillage *Fertility *Rotation & 0.585 & 0.765 \\
\hline
\end{tabular}

${ }^{\mathrm{z}}$ Block effects were not significant in both analyses.

lack of soil loosening associated with annual tillage. As would be expected, soil BD was greater in the 10- to 20than in the 0- to 10-cm depth interval under NT (Figure 1). However, in contrast to that expected, soil BD was also greater in the 10 - to 20 - than in the 0 - to $10-\mathrm{cm}$ depth interval under CT (Figure 1). Soil BD was similar in the 10 - to 20 -cm depth interval between tillage treatments, averaging $1.41 \mathrm{~g} / \mathrm{cm}^{3}$ across both tillage treatments (Figure 1). Though the 10 - to $20-\mathrm{cm}$ soil depth interval typically has a greater clay content than in the top $10 \mathrm{~cm}$ in the alluvial soils of the Mississippi River Delta region of eastern Arkansas, and since soil BD has been shown to be directly related to clay content [17], it appears that the mixing of soil due to mechanical cultivation in CT was not substantial enough to eliminate dissimilarities among depth intervals as expected. The elevated BD in 10- to 20-cm depth interval in CT, in relation to the top $10 \mathrm{~cm}$, can be partially explained by the presence of a prominent plow pan within the sampled depth. A prominent plow layer of approximately the $10 \mathrm{~cm}$ depth is common throughout much of the rowcrop cultivated area in the Delta region of eastern Arkansas due the long history of annual mechanical disruption by tillage [48]. The assumption of a plow pan present in CT plots is consistent with previous observations made in this same study in spring 2006, which showed that CT had significantly greater penetration resistance than to NT beginning at the 12.7-cm depth $(\mathrm{P}<0.001)$ and continuing through the 25.4-cm depth $(\mathrm{P}=0.031)$ [43].

A subsurface compacted layer can be created when fine soil particles dispersed during tillage settle into spaces of the soil matrix that were previously occupied 


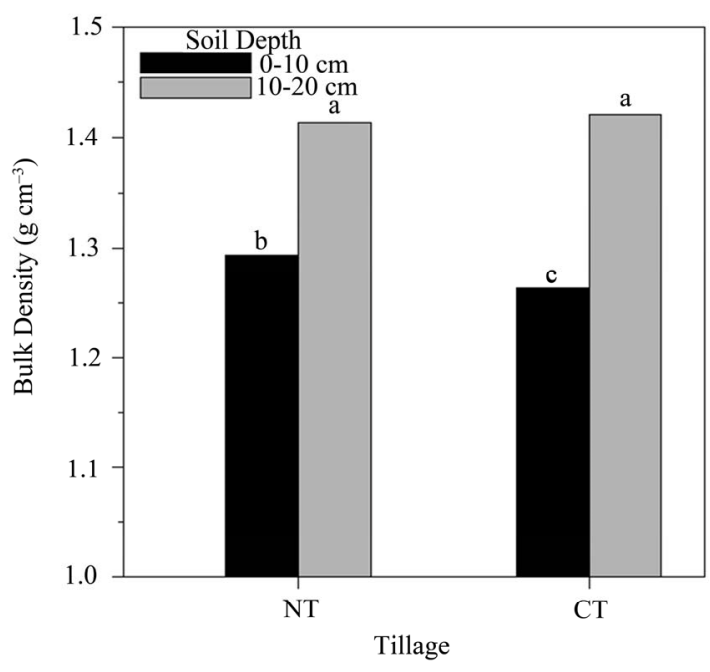

Figure 1. Tillage and soil depth effects on soil bulk density averaged across crop rotations and soil fertility levels after 10 years of consistent management. Tillage treatments included no-tillage (NT) and conventional tillage (CT). Bars with different letters are significantly different at the 0.05 level.

by air, thus elevating soil BD. Furthermore, this subsurface compacting effect of the soil can be increased by repeated machinery traffic [20] and prolonged flooded conditions for rice production, which causes the slaking of soil aggregates [49].

Another possible contribution to greater BD in 10-to 20-cm depth in both tillage treatments was likely related to numerically lower SOM compared to the top $10 \mathrm{~cm}$. Similar to previous research $[6,15]$, the SOM concentration was $43.17 \%$ greater in the 0 - to $10-(2.129 \%)$ than in the $10-$ to $20-\mathrm{cm}$ depth $(1.487 \%)$ when averaged across all other treatment combinations $(\mathrm{P}<0.001$; Table 3; Table 4). Although SOM concentration did not differ significantly among tillage treatments, there was a significant interaction effect between crop rotation and sampling depth on SOM $(\mathrm{P}<0.050$; Table 3). Soil OM differed among crop rotations in the top $10 \mathrm{~cm}$, but was similar among all crop rotations in the $10-$ to $20-\mathrm{cm}$ depth interval. Overall, soil BD magnitudes measured in this study were well-below the typical $1.60 \mathrm{~g} / \mathrm{cm}^{3}$ threshold at which root penetration has been reported to become limited when the soil is dry [17]. The results of this study were similar to those reported from a 3-yr rice-wheat rotation in a sandy-loam soil in India [50] and from a rice-rotation study in a clay-loam soil in India [51].

Averaged across soil depth, soil BD also differed $(\mathrm{P}=$ 0.002 ) among rotation-tillage-fertility treatment combinations (Table 3). However, few consistent trends among treatment combinations and their effect on soil BD existed. It is interesting to note that after 10 years of continuous rice, soil BD was 3.76\% greater under CT
Table 4. Crop rotation-soil depth treatment combination effects on soil organic matter percentage averaged across tillage and fertility treatments after 10 years of consistent management. Crops included rice $(\mathrm{R})$, soybean $(\mathrm{S})$, corn $(\mathrm{C})$, and winter wheat $(\mathrm{W})$. Soil depths included $0-\mathrm{cm}$ to $10-\mathrm{cm}$ and $10-\mathrm{cm}$ to 20-cm.

\begin{tabular}{ccc}
\hline & \multicolumn{2}{c}{ Soil Organic Matter (\%) } \\
\hline Rotation & $0-10 \mathrm{~cm}$ & $10-20 \mathrm{~cm}$ \\
$\mathrm{R}$ & 2.085 & 1.428 \\
$\mathrm{RS}$ & 1.952 & 1.533 \\
$\mathrm{SR}$ & 1.982 & 1.479 \\
$\mathrm{RC}$ & 2.152 & 1.473 \\
$\mathrm{CR}$ & 2.237 & 1.499 \\
$\mathrm{R}(\mathrm{W})$ & 2.388 & 1.528 \\
$\mathrm{R}(\mathrm{W}) \mathrm{S}(\mathrm{W})$ & 2.192 & 1.535 \\
$\mathrm{~S}(\mathrm{~W}) \mathrm{R}(\mathrm{W})$ & 2.201 & 1.469 \\
$\mathrm{RSC}$ & 2.117 & 1.446 \\
$\mathrm{RCS}$ & 1.984 & 1.478 \\
\hline \multicolumn{2}{c}{ The least significant difference at the 0.05 level $\left(\right.$ LSD $\left._{0.05}\right)$ to compare } \\
among different rotations at the same depth is 0.240. All values of the \\
same rotation with a different depth and different rotation with a dif- \\
ferent depth are significantly different.
\end{tabular}

$\left(1.38 \mathrm{~g} \cdot \mathrm{cm}^{-3}\right)$ than NT $\left(1.33 \mathrm{~g} \cdot \mathrm{cm}^{-3}\right)$ in both soil fertility regimes (Table 5), which, as mentioned previously, may presumably be caused by the settlement of fine soil particles as a result of soil disruption from tillage combined with flooded growing conditions. This outcome suggests that greater BD associated with negative effects on plant growth and/or yield may have a greater tendency to develop in time under CT than under NT regardless of soil fertility regime. In addition, compared to continuous NT (R) $\left(1.33 \mathrm{~g} \cdot \mathrm{cm}^{-3}\right)$, soil BD was $3.00 \%$ greater in the NT $\mathrm{R}(\mathrm{W})$ rotation $\left(1.37 \mathrm{~g} \cdot \mathrm{cm}^{-3}\right)$ under both soil fertility regimes and SOM was greater in the $\mathrm{R}(\mathrm{W})$ rotation in the 0 - to 10 -cm depth (2.388\%) under both tillage treatments and fertility regimes than (R) (2.085\%; Table 4$)$. This result demonstrates that, despite producing a greater amount of aboveground residue in the $\mathrm{R}(\mathrm{W})$ rotation compared to continuous rice due to twice the number of high-residue-producing crops per year (Table 2), the effects of greater surface SOM decreasing soil BD are not quickly realized. However, with twice the number of crops grown per year, the $\mathrm{R}(\mathrm{W})$ rotation also experienced twice the number of machinery passes compared to continuous rice, so the elevated $\mathrm{BD}$ in the $\mathrm{R}(\mathrm{W})$ rotations may possibly be associated with compaction due to machinery traffic. Furthermore, penetration resistance data collected in 2006 showed that the $\mathrm{R}(\mathrm{W})$ rotation had greater resistance in the 5- to $15-\mathrm{cm}$ depth (ranging from 2.5 to $4.4 \mathrm{MPa}$ ) than any other rotation in the study, whereas the CR rotation had the lowest resistance (ranging from 1.6 to $2.8 \mathrm{MPa}$ ) over the same depth 
Table 5. Crop rotation-tillage-fertility treatment combination effects on soil bulk density averaged across soil depths after 10 years of consistent management. Crops included rice (R), soybean (S), corn (C), and winter wheat (W). Tillage treatments included no-tillage and conventional tillage. Soil fertility treatments included optimal and sub-optimal.

\begin{tabular}{ccccc}
\hline \multirow{2}{*}{ Rotation } & \multicolumn{3}{c}{ Soil Bulk Density $\left(\mathrm{g} / \mathrm{cm}^{3}\right)^{\mathrm{a}}$} \\
\cline { 2 - 5 } & Optimal & No-Tillage & Conventional Tillage \\
\cline { 2 - 4 } & 1.32 & Sub-Optimal & Optimal & Sub-Optimal \\
\hline R & 1.39 & 1.35 & 1.37 & 1.39 \\
RS & 1.36 & 1.41 & 1.34 & 1.35 \\
SR & 1.38 & 1.36 & 1.32 & 1.34 \\
RC & 1.31 & 1.35 & 1.35 & 1.36 \\
CR & 1.35 & 1.39 & 1.33 & 1.34 \\
R(W) & 1.40 & 1.37 & 1.37 & 1.39 \\
R(W)S(W) & 1.33 & 1.34 & 1.35 & 1.32 \\
S(W)R(W) & 1.34 & 1.33 & 1.30 & 1.32 \\
RSC & 1.34 & 1.32 & 1.32 & 1.35 \\
RCS & & & 1.33 & \\
\hline
\end{tabular}

${ }^{\mathrm{a}}$ The least significant difference at the 0.05 level $\left(\mathrm{LSD}_{0.05}\right)$ to compare among same tillage, same fertility, and different rotation combinations is 0.04 . The $\mathrm{LSD}_{0.05}$ to compare among same tillage, different fertility, and same rotation combinations is 0.04 . The LSD 0.05 to compare among different tillage, same or different fertility, and same rotation combinations is 0.03 . The $\mathrm{LSD}_{0.05}$ to compare among same tillage, different fertility, and different rotation combinations is 0.07 . The $\mathrm{LSD}_{0.05}$ to compare among different tillage, same or different fertility, and different rotation combinations is 0.05 .

interval [43]. The greater resistance in the R(W) was reported to be caused from a lack of a strong, deep-penetrating root system as is present in the CR rotation [43].

With the exception of in the CR rotation under NT, where soil BD was greater with the sub-optimal than with the optimal soil fertility regime, soil fertility regime did not affect soil BD within tillage treatments in any rotation (Table 5). Despite differences from the hypothesized outcome of BD in relation to fertility level, SOM concentration was $4.18 \%$ greater in optimal $(1.845 \%)$ than in the sub-optimal $(1.771 \%)$ fertility regime $(\mathrm{P}=0.029)$. Soil $\mathrm{BD}$ within the same fertility regime differed between tillage treatments in all rotations except in the RC, S(W)R(W) and RCS rotations (Table 5). In contrast to that hypothesized, soil BD was unrelated to the number of times a rice or high-residueproducing crop (i.e., rice, corn, and wheat; Table 2) was grown over the 10-yr study period in either soil depth interval separately or averaged across both soil depths. However, as might be expected, SOM concentration was highly correlated with the number of times a highresidue-producing crop (i.e., rice, corn, and wheat; Table 2) was grown over the 10 -yr study period in the top 10 $\mathrm{cm}(\mathrm{r}=0.89, \mathrm{P}=0.001)$ and when averaged across both soil depths $(r=0.90, \mathrm{P}<0.001)$.

\section{AGRONOMIC IMPLICATIONS}

This study demonstrated that after 10 years of consistent management soil BD was slightly greater under NT than CT in the top $10 \mathrm{~cm}$, but soil BD was similar between NT and CT in the 10- to 20-in depth interval. These results indicate that, despite $\mathrm{BD}$ values observed in this study being lower than the common threshold BD above which it is believed that root penetration is negatively affected, an infrequent deep-tillage operation may be needed to disrupt the developing zone of relatively compacted soil below the plow layer under CT. This study also demonstrated that soil BD differed among common rice-based cropping systems, but that differences in near-surface soil BD were not clearly related to the number of high-residue-producing crops, such as rice, corn, and wheat, that were produced in a given time period. The frequent cycling between relatively dry and nearly to completely saturated soil conditions over the course of the rice growing season likely contributes to a more complex relationship between soil $\mathrm{BD}$ and residue returned to the soil and/or SOM accumulation. It appears that, even after 10 years of continuous CT or NT rice production on a silt-loam soil in the Mississippi River Delta region of eastern Arkansas, substantially increased near-surface soil BD has not developed to the point where soil compaction would be a likely culprit responsible for potential early season stand establishment or crop yield differences among rice-based copping systems.

\section{ACKNOWLEDGEMENTS}

This research was partially funded by the Arkansas Rice Research and Promotion Board. Field assistance provided by Terry Sells and Daniel McCarty is gratefully acknowledged.

\section{REFERENCES}

[1] Karlen, D.L., Andrews, S.S., Wienhold, B.J. and Zobeck, T.M. (2008) Soil quality assessment: Past, present, and future. Journal of Integrated Biosciences, 6, 3-14.

[2] Pulleman, M.M., Bouma, J., van Essen, E.A. and Meijles, 
E.W. (2000) Soil organic matter content as a function of different land use history. Soil Science Society of America Journal, 64, 689-693. doi:10.2136/sssaj2000.642689x

[3] Karlen, D.L., Mausbach, M.J., Doran, J.W., Cline, R.G. Harris, R.F. and Schuman, G.E. (1997) Soil quality: A concept, definition, and framework for evaluation. Soil Science Society of America Journal, 61, 4-10. doi:10.2136/sssaj1997.03615995006100010001x

[4] Wolf, B. and Snyder, G.H. (2003) Sustainable soils: The place of organic matter in sustainable soils and their productivity. Food Products Press, New York.

[5] Carter, M.C., Dean, T.J., Wang, Z. and Newbold, R.A. (2006) Impacts of harvesting and post harvesting treatments on soil bulk density, soil strength, and early growth of Pinus taeda in the Gulf Coastal Plain: A long-term soil productivity affiliated study. Canadian Journal of Forest Research, 36, 601-614. doi:10.1139/x05-248

[6] Diana, G., Beni, C. and Marconi, S. (2008) Organic and mineral fertilization: Effects on physical characteristics and boron dynamic in an agricultural soil. Communications in Soil Science and Plant Analysis, 39, 1332-1351. doi:10.1080/00103620802004037

[7] Elliot, W.J., Page-Dumroese, D.S. and Robichaud, P.R. (1998) The effect of forest management on erosion and soil productivity. In: Lal, R., Ed., Soil quality and erosion. St. Lucie Press, Boca Raton, Florida, 195-209.

[8] Page-Dumroese, D.S., Jurgensen, M.F., Tiarks, A.E., Ponder, Jr.F., Sanchez, F.G., Fleming, R.L., Kranabetter, J.M., Powers, R.F., Stone, D.M., Elioff, J.D. and Scott, D.A. (2006) Soil physical property changes at the North American long-term soil productivity study sites: 1 and 5 years after compaction. Canadian Journal of Forest Research, 36, 551-564. doi:10.1139/x05-273

[9] Souch, C.A., Martin, P.J., Stephens, W. and Spoor, G. (2004) Effects of soil compaction and mechanical damage at harvest on growth and biomass production of short rotation coppice willow. Plant and Soil, 263, 173-182. doi:10.1023/B:PLSO.0000047734.91437.26

[10] Amuri, N. and Brye, K.R. (2008) Residue management practice effects on soil penetration in a wheat-soybean double-crop production system. Soil Science, 173, 779791. doi:10.1097/SS.0b013e31818a54b4

[11] Ehlers, W., Köpke, U., Hesse, F. and Böhm, W. (1983) Penetration resistance and root growth of oats in tilled and untilled loess soil. Soil and Tillage Research, 3, 261-275. doi:10.1016/0167-1987(83)90027-2

[12] Hirth, J.R., McKenzie, B.M. and Tisdall, J.M. (2005) Ability of seedling roots of Lolium perenne L. to penetrate soil from artificial biospores is modified by soil bulk density, biospore angle and biospore relief. Plant and Soil, 272, 327-336. doi:10.1007/s11104-004-5764-1

[13] Krizek, D.T., Ritchie, J.C., Sadeghi, A.M., Foy, C.D., Rhoden, E.G., Davis, J.R. and Camp, M.J. (2003) A four-year study of biomass production of eastern gamagrass grown on an acid compact soil. Communications in Soil Science and Plant Analysis, 34, 457-480. doi:10.1081/CSS-120017832

[14] Lampurlanés, J. and Cantero-Martínez, C. (2003) Soil bulk density and penetration resistance under different tillage and crop management systems and their relation- ship with barley root growth. Agronomy Journal, 95, 526-536. doi:10.2134/agronj2003.0526

[15] Son, Y., Yang, S.Y., Jun, Y.C., Kim, R.H., Lee, Y.Y., Hwang, J.O. and Kim, J.S. (2003) Soil carbon and nitrogen dynamics during conversion of agricultural lands to natural vegetation in central Korea. Communications in Soil Science and Plant Analysis, 34, 1511-1527. doi:10.1081/CSS-120021293

[16] Karamanos, A.J., Bilalia, D. and Sidiras, N. (2004) Effects of reduced tillage and fertilization practices on soil characteristics, plant water status, growth and yield of upland cotton. Journal of Agronomy and Crop Science, 190, 262-276. doi:10.1111/j.1439-037X.2004.00101.x

[17] Brady, N.C. and Weil, R.R. (2008) The nature and properties of soil, 14th Edition, Prentice-Hall, Upper Saddle River, New Jersey.

[18] Afyuni, M. and Wagger, M.G. (2006) Soil physical properties and bromide movement in relation to tillage system. Communications in Soil Science and Plant Analysis, 37, 541-556. doi:10.1080/00103620500449393

[19] Chan, K.Y. (2002) Bulk density. In: Lal, R. Ed., Encyclopedia of Soil Science, Marcel Dekker, New York, 128-130.

[20] Mahboubi, A.A., Lal, R. and Fausey, N.R. (1993) Twenty-eight years of tillage effect on two soils in Ohio. Soil Science Society of America Journal, 57, 506-512. doi:10.2136/sssaj1993.03615995005700020034x

[21] Radcliffe, D.E., Toller, E.W. and Hargrove, W.L. (1988) Effect of tillage practice on infiltration and soil strength of a Typic Hapludult soil after ten years. Soil Science Society of America Journal, 52, 798-804. doi:10.2136/sssaj1988.03615995005200030036x

[22] Vervoort, R.W., Dabney, S.M. and Romkens, M.J.M. (2001) Tillage and row position effects on water and solute infiltration characteristics. Soil Science Society of America Journal, 65, 1227-1234. doi:10.2136/sssaj2001.6541227x

[23] Khan, A.R., Chandra, D., Quraishi, S. and Sinha, R.K. (2000) Soil aeration under different soil surface conditions. Journal of Agronomy and Crop Science, 185, 105112. doi:10.1046/j.1439-037X.2000.00417.x

[24] Girma, K., Martin, K.L., Anderson, R.H., Arnall, D.B., Brixey, K.D., Casillas, M.A., Chung, B., Dobey, B.C., Kamenidou, S.K., Kariuki, S.K., Katsalirou, E.E., Morris, J.C., Moss, J.Q., Rohla, C.T., Sudbury, B.J., Tubana, B.S. and Raun, W.R. (2006) Mid-season prediction of wheat-grain yield potential using plant, soil, and sensor measurements. Journal of Plant Nutrition, 29, 873- 897. doi:10.1080/01904160600649187

[25] Townshend, J.L. and Webber, L.R. (1971) Movement of Pratylenchus penetrans and moisture characteristics of three Ontario soils. Nematologica, 17, 47-57. doi:10.1163/187529271X00404

[26] Soyelu, L.O., Ajayi, S.A., Aluko, O.B. and Fakorede, A.B. (2001) Varietal differences in development of maize (Zea mays L.) seedlings on compacted soils. Journal of Agronomy and Crop Science, 186, 157-166. doi:10.1046/j.1439-037X.2001.00467.x

[27] Cassel, D.K., Raczkowski, C.W. and Denton, H.P. (1995) Tillage effects on corn production and soil physical properties. Soil Science Society of America Journal, 59, 1436-1443. 
doi:10.2136/sssaj1995.03615995005900050033x

[28] Grevers, M.C.L. and Bomke, A.A. (1986) Tillage practices on a northern clay soil: Effect of sod breaking methods on crop production and soil physical properties. Canadian Journal of Soil Science, 66, 385-395. doi:10.4141/cjss86-041

[29] Lal, R., Mahboubi, A.A. and Fausey, N.R. (1994) Long-term tillage and rotation effects on soil properties of a central Ohio soil. Soil Science Society of America Journal, 58, 517-522. doi:10.2136/sssaj1994.03615995005800020038x

[30] NeSmith, D.S., Radcliffe, D.E., Hargrove, W.L., Clark, R.L. and Toller, E.W.. (1987) Soil compaction in double-cropped wheat and soybean on an Ultisol. Soil Science Society of America Journal, 51, 183-186.

[31] Myers, J.L. and Wagger, M.G. (1996) Runoff and sediment loss from tillage systems under simulated rainfall. Soil and Tillage Research, 39, 115-129. doi:10.1016/S0167-1987(96)01041-0

[32] Wagger, M.G. and Denton, H.P. (1989) Influence of cover crop and wheel traffic on soil physical properties in continuous no till corn. Soil Science Society of America Journal, 53, 1206-1210. doi:10.2136/sssaj1989.03615995005300040036x

[33] United States Department of Agriculture (USDA) (2009) Crop Explorer: United States-area, yield, and production.

http://www.pecad.fas.usda.gov/cropexplorer/default_pop win.cfm?obj_name=util/new_get_psd_data.cfm\&regioni d=us.

[34] Wilson, C.E.Jr. and Runsick, S.K. (2008) Trends in rice production. In: Norman, R., Meullenet, J.-F. and Moldenhauer, K.A.K., Eds., B. R. Wells, Rice Research Studies 2007, Research Series 560, University of Arkansas Agricultural Experiment Station, Fayetteville, 11-20.

[35] National Agricultural Statistics Service (NASS) (2009) U.S. and all states data-Crops: Planted, harvested, yield, production, price (MYA), value of production. http://www.nass.usda.gov/Data_and_Statistics/Quick_Stats/.

[36] Norman, R.J., Wilson, C.E.Jr. and Slaton, N.A. (2003) Soil fertilization and mineral nutrition in U.S. mechanized rice culture. In: Smith, C.W. and Dilday, R.H., Eds., Rice: Origin, History, Technology, and Production, John Wiley \& Sons, Inc., New Jersey, 331-411.

[37] Lima, A.C.R., Hoogmoed, W.B., Pauletto, E.A. and Pinto, L.F.S. (2009) Management systems in irrigated rice affect physical and chemical properties. Soil and Tillage Research, 103, 92-97. doi:10.1016/j.still.2008.09.011

[38] Salinas-Garcia, J.R., Hons, F.M. and Matocha, J.E. (1997) Long-term effects of tillage and fertilization on soil organic matter dynamics. Soil Science Society of America Journal, 61, 152-159. doi:10.2136/sssaj1997.03615995006100010023x

[39] Xu, Y., Chen, W. and Shen, Q. (2007) Soil organic car- bon and nitrogen pools impacted by long-term tillage and fertilization practices. Communications in Soil Science and Plant Analysis, 38, 347-357. doi:10.1080/00103620601172332

[40] National Resources Conservation Service (NRCS) (2008). Web soil survey. Data from survey from November 12, 2008.

http://websoilsurvey.nrcs.usda.gov/app/WebSoilSU-vey.a spx.

[41] Brye, K.R., Slaton, N.A., Savin, M.C., Norman, R.J. and Miller, D.M. (2003) Short-term effects of land leveling on soil physical properties and microbial biomass. Soil Science Society of America Journal, 67, 1405-1417. doi:10.2136/sssaj2003.1405

[42] Southern Region Climate Center (SRCC) (2009) Temperature (F) and precipitation (in) normals (1971-2000): Stuttgart 9 ESE. Louisiana State University. Baton Rouge, Baton Rouge.

http://www.srcc.lsu.edu/stations/index.php?action=meta \&network station id=030240.

[43] Schmid, B.T. (2008) Conservation tillage effects on soil physical and chemical properties in rice production in the Arkansas delta. Master's Thesis, University of Arkansas, Fayetteville.

[44] Slaton, N.A. (2001) Rice production handbook. Handbook. MP 192. University of Arkansas Cooperative Extension Service, Little Rock.

[45] Ashlock, L. (2000) Arkansas soybean handbook. Handbook. MP 197. University of Arkansas Cooperative Extension Service, Little Rock.

[46] Espinoza, L. and Ross, J. (2003) Corn production handbook. Handbook. MP 437. University of Arkansas Cooperative Extension Service, Little Rock.

[47] Johnson, W.F.Jr. (1999) Arkansas wheat production and management. Handbook. MP 404. University of Arkansas Cooperative Extension Service, Little Rock.

[48] Harper, T.W., Brye, K.R., Daniel, T.C., Slaton, N.A. and Haggard, B.E. (2008) Land use effects on runoff and water quality on an eastern Arkansas soil under simulated rainfall. Journal of Sustainable Agriculture, 32, 231-253. doi:10.1080/10440040802170806

[49] Hillel, D. (2004) Introduction to soil physics. Elsevier Academic Press, San Diego.

[50] Gangwar, K.S., Singh, K.K., Sharma, S.K. and Tomar, O.K. (2006) Alternative tillage and crop residue management in wheat after rice in sandy loam soils of Indo-Gangetic plains. Soil and Tillage Research, 88, 242-252. doi:10.1016/j.still.2005.06.015

[51] Kar, G. and Kumar, A. (2009) Evaluation of post-rainy season crops with residual soil moisture and different tillage methods in rice fallow of eastern India. Agricultural Water Management, 96, 931-938. doi:10.1016/j.agwat.2009.01.002 